International Journal of

Advanced Science and Convergence

ISSN : 2619-8150

Volume 3, Number 3, September 2021

3 https://doi.org/10.22662/IJASC.2021.3.3.015

\title{
The Effect of Influencer Influence on Recommendation Intention: Focused on TikTok Live Commerce in China
}

\author{
Yufei Chen ${ }^{1}$, Seogju Chang ${ }^{2}$ \\ ${ }^{1}$ Student, Department of Business Administration, Honam University, Republic of Korea \\ ${ }^{2}$ Professor, Department of Business Administration, Honam University, Republic of Korea
}

\begin{abstract}
Background/Objectives : This study takes focusing on TikTok live commerce in China, divides the influence of internet celebrity into 2 factors, such as charm and professionalism, and finds out its influence on the intention of recommendation and the media effect of input and perceived value. In order to confirm this argument, this study makes an empirical analysis on Chinese native Chinese and Chinese students in Korea. Methods/Statistical ana lysis :The analysis results show that the charm and professionalism of online red have a positive impact on recom mendation intention, and confirm the media role of investment and perceived value in the relationship between $\mathrm{i}$ nternet celebrity`s influence and recommendation intention. Findings : Based on the above results, it is confirmed that the charm and professionalism of internet celebrity are important reasons to improve users' recommendation intention. Improvements/Applications : In addition, the enlightenment is put forward through this study, and th e limitations and future research directions are discussed.
\end{abstract}

key word

Influence, Live commerce, Live streaming technology, Data science, TikTok

\footnotetext{
Corresponding author: Y. F. Chen

jannefulz0101@naver.com

- Manuscript received August 12, 2021

- Revised September 5, 2021 ; Accepted September 20, 2021

- Date of publication September 30, 2021

(c) The Academic Society of Convergence Science Inc.

2619-8150 ( 2019 IJASC. Personal use is permitted, but republication/redistribution requires IJASC permission.
} 


\section{INTRODUCTION}

While the frequency of offline product purchases has sharply decreased as the amount of time consumers go out has decreased due to the coronavirus outbreak in 2019, non-face-to-face online purchases, namely contactless consumption, are becoming common around the world.

With the spread of smart devices and the rapid development of technology such as $5 \mathrm{G}$, various media content can be consumed regardless of the time and place. In this environment, consumers have changed into a consumption pattern that can communicate and share large amount of condensed information within a short time through social network services and the media. In particular, a variety of short video services known as short form, representative of snack culture, is attracting attention as a new form of communication.

While there are many short clip platforms in China, Tik Tok is acknowledged as the platform with the greatest influence. TikTok is a short clip platform created in September 2016 by the Byte Dance company to create and share short 15 -second videos. In less than a year since TikTok appeared, the volume of daily playback of videos has exceeded 1 billion, where according to statistics, in the first quarter of 2021, the number of Day Active Users (DAU) reached 6.8-700 million. In addition, the development of TikTok became not only limited to China, where by the end of 2020, the number of users of the international version of the TikTok app surpassed 500 million, surpassing that of Facebook and occupying first place in overall downloads within the App Store. TikTok not only provides short videos, but also provides live commerce functions since 2018, and as the 'non-face-to-face culture' spread as COVID19 spread, live commerce emerged as a major online shopping channel and has continued to grow explosively.

Live commerce is a compound word of live streaming and e-commerce, which entails the notion of enabling real-time communication between sellers and consumers in comparison to conventional online shopping, and provides detailed and vibrant information vividly through the live screen. It not only delivers, but also provides entertainment. Live commerce in China started to become popular after 2015 and began actively growing in 2018, and is predicted to continue to grow significantly in the future.
At the foundation of the development of live commerce in China, individual influencers (SNS Celebrities), exert strong influence, playing a major role and emerging one after another through various fields [1]. In China, they call influencers 'Wang Hong', and these 'Wang Hong's are in the front lines of the Chinese trend as an opinion leader to the extent that the term 'Wang Hong Economy' was coined as it is changing the sales process and industry landscape. The Chinese Wang Hong industry has vastly grown to an annual scale of 17 trillion won as the products sold by the Wang Hong became a so-called "big hit," and by November 2020, 22 million influencers earned 41.7 billion won on the TikTok app alone across the globe.

Influencers who are gaining popularity in TikTok live commerce in China, provide different information based on their product-related experiences and respond immediately to the comments of users to induce the users' purchase. Style and friendly service are becoming factors that gain popularity among general users [2]. Therefore, influencers who are rapidly developing in China, have great influence and potential, and can be linked to the consumption behavior of live commerce users, where it is expected to continue to grow significantly in the future.

Also, if you look at the current research so far, there are many preceding studies about influencers, but various studies have been done mainly through case analysis within the field of advertising. There is insufficient academic discussion on the specific characteristics of TikTok, the most popular platform in China and how it affects consumer behavior. Therefore, this study aims to investigate the relationship between recommendation intention and charm and professionalism, characteristics of influencers who secure many fans and influential people in Chinese TikTok live commerce in China, and how they increase viewing immersion and perceived value, creating a "live streaming + influencer" model. Through this, the study is significant in that it suggests implications for the sustainable development of platforms and sales companies that provide live commerce functions and improve their marketing strategies using influencers. 


\section{THEORETICAL BACKGROUND AND RESEARCH HYPOTHESIS}

\section{A. Research related to Influencer Characteristics}

influencer is a leader in charge of creating and presenting content on live streaming platforms and communicating with consumers. [3] suggested the similarity, reliability, professionalism, and charm of information sources as characteristics that have high effect in persuasion. According to a study on a number of influencers conducted in the field of live commerce, the characteristics of influencers were divided into several dimensions, but charm and professionalism were verified as components that were, for the most part, essential [4-9]. In addition, it has been found that in live streaming, even if various influencers present and sell the same product, the level of understanding and attitude of the audience differs depending on who the influencer is [5]. Subsequently, this study intends to analyze the characteristics of influencers by categorizing them based on their charm and expertise.

\section{1)Charm}

Charm is defined as the degree to which a person judges how much they like and feel positive of the other person and about their presence[10]. Charm is defined as 'the power to captivate people's hearts', and is also defined as the image of an individual's appearance that induces favorable responses from others [11]. In the field of live commerce, charm refers to the degree to which an audience feels attracted and favorable to influencers who are performing the live streaming [5]. With the expansion of various channels and active relationships formed through the media, charm plays an important role in forming values not only in the relationships between people we meet in our daily lives, but also in relationships that we have with celebrities, including influencers in the media [12].

\section{2)Expertise}

Expertise refers to having considerable knowledge and experience in a specific field or to show performance above the level of the ordinary population within a certain area [13]. Expertise also means that consumers perceive that influencers are well aware of their field and have accurate knowledge [14]. In the field of marketing, many researchers have verified that the expertise of influencers affects behavioral intention, including purchase and usage intentions [15-16, 7].

\section{B. Flow}

Flow in English, was first proposed by [17] in 1974, where according to his theory, it refers to a state in which a person is psychologically immersed in something. Different researchers have different definitions of flow. According to the study by [18], flow is defined as a state of being deeply immersed in a specific event or object, not recognizing the passage of time and not paying attention to anything other than what one is concentrating on. [12] defines flow as a state in which immersion is completely focused on the content of the influencer, not recognizing time or space, and forgetting any thoughts about oneself and rather feeling joy.

\section{Perceived Value}

Perceived value is rooted in the consumption value theory and is based on the perception of what consumers have consumed and provided. It refers to a measure of satisfaction with utility based on emotional, economic, quality, and social values obtained by investing in recognized tangible and intangible goods [19-23]. An individual's perceived value has been suggested as one of the causal variables that not only induce the purchase of a product, but also the decision to use a service or to inform others of it [24-25]. Moreover, it has been verified that the perceived value in terms of consumers in various fields has a positive effect on the purchase behavior starting from the pre-purchase stage to consumption choice behavior, as well as post-purchase recommendations and repurchases made [23, 2627].

\section{Recommendation Intention}

Recommendation intention refers to the consumer's most representative behavioral intention to inform various people on information 
about the service or product they used in which they induce active purchases and visits of other consumers [28]. Recommendation intention has been studied as a 'word of mouth phenomenon' in consumer behavior research, where it is defined as a positive evaluation of experience [29]. Most potential customers are not limited by the commercial information received through mass media, but tend to trust information that is provided through word-of-mouth communication through family and friends [30-31]. Recommendation intention is derived among consumers to increase the reliability of information and to influence the recipient to accept the content with more ease [32].

\section{E. The Relationship between Influencer Characteristics and Engagement}

After your paper is accepted, you will be asked to [33] divided the characteristics of influencers into charm, vividness, and professionalism, while [16] distinguished four sub-factors of influencer as charm, reliability, professionalism, and intimacy. [34] used the components of influencer influence as charm, professionalism, and vitality. Based on this, this study classifies the characteristics of influencers into charm and professionalism.

[35] verified that the charm and professionalism of online one-person personal broadcasting BJ had a positive effect on viewing immersion, while it was revealed that the charm of an influencer significantly affects the immersion experience of viewers in a study on the viewing satisfaction and subscription intention of single influencer broadcasting users by [36]. [12] suggests that charm, the quality of Chinese influencers, has a positive (+) effect on immersion through empirical analysis based on the SOR model. [15] found that charm and professionalism of influencers within the field of live commerce have a meaningful effect on immersion. Based on these previous studies, the following hypotheses were established.

Hypothesis 1: The charm of influencers will have a positive $(+)$ effect on engagement.

Hypothesis 2: Influencer's expertise will have a positive (+) effect on flow.

\section{F. The Relationship between Influencer Characteristics and Perceived Values}

[37] suggested that the higher the charm of the influencer and the stronger the professionalism in the marketing process, the more influence there will be on the perceived value of the consumer. By sharing influencers' actual experiences, professional knowledge and information within a specific field, influencers have greater influence on consumers' perceptions and perceived value or consumption behavior[38]. In [39]'s consumer behavior study, the characteristics of SNS influencers were classified into charm, professionalism, authenticity, and interactivity, where it was proven that they have a positive effect on perceived value. In a study by [33], it was found that the charm of live commerce information sources had a positive (+) effect on the hedonistic value, a sub-factor of the perceived value. The consumption semiotic analysis study of [40] investigated the influential relationship between charm, professionalism, interactivity, reliability, and perceived value, as the characteristics of influencers.

Based on these previous studies, the following hypotheses were established.

Hypothesis 3: The charm of influencers will have a positive $(+)$ effect on perceived value.

Hypothesis 4: Influencer's expertise will have a positive (+) effect on perceived value.

\section{G. The Relationship between Flow and Recommendation Intention}

[41] demonstrated that commitment has a direct effect on loyalty, which includes positive word of mouth and recommendation intention, and [42] found that observing immersion had a significant effect on the recommendation intention of others in the field of motivating viewers to watch TV. In a study on the characteristics of restaurant company brand community by [43], it was found that the higher the interaction between the brand community and the more positive the immersion, the higher the positive (+) effect had on recommendation intention. In a study on the effect of SNS characteristics on restaurants' immersion, trust, and behavioral intention by [44], he said that immersion had a significant effect on word of 
mouth intention, which encompasses the same notion as recommendation intention. [45]'s study on the fairness of franchise headquarters investigated the relationship between commitment and recommendation intention.

Based on this relationship, the following hypothesis was established.

Hypothesis 5: Commitment will have a positive (+) effect on recommendation intention.

\section{H. The Relationship between Perceived Value and Recommendation Intention}

[46] classified the perceived value of high-end $h$ otel users into five dimensions: monetary, emotion al, social, transactional, and acquired value, where they verified that except for the acquired value, th ese aspects had a positive effect on recommendati on intention. In [47]'s study of Chinese telecommu nication service characteristics, it was found that $p$ erceived value had a significant effect on behavior al intention including purchase intention and reco mmendation intention. The study on hotel brand $\mathrm{i}$ mage by [48], investigated the relationship betwee $\mathrm{n}$ perceived value, satisfaction, and recommendati on intention, where it was found that the more posi tive the hotel brand image, the more it had a positi ve (+) influence on perceived value, and confirme $d$ that the higher the value, the higher the satisfacti on, namely the higher the positive effect on recom mendation intention. In a study on the behavioral i ntentions of Chinese tourists visiting Korea, [49] c onfirmed that the aspect of selecting a tourist desti nation had a positive (+) effect on the perceived va lue, and that the perceived value had a significant effect on the recommendation intention. [50] classi fy perceived value in the field of individual media content as emotional value, intellectual value, and economic value, and has derived the conclusion th at each value significantly affects recommendation intention. Based on this relationship, the followin $\mathrm{g}$ hypothesis was established.

Hypothesis 6: Perceived value will have a positi ve (+) effect on recommendation intention.

\section{Mediated Effect of Flow}

[51] verified the partial mediating role of immersion in a study on the mediating role of flow and the use of Afreeca TV. [16] confirmed that influencer attachment has passed through immersion to reach purchase intention, and demonstrated the mediating effect of immersion. The study by [15] verifies the mediating role of immersion in the relationship between the material of Wang Hong and consumers' impulsive purchases in live broadcasting. In addition, according to a study by [9], it was found that immersion has a mediating effect between charm, professionalism with the level of recognition and purchase intention of a live commerce show host.

Hypothesis 7: Engagement will mediate the relationship between influencers' charm and recommendation intention.

Hypothesis 8: Engagement will mediate the relationship between influencers' expertise and recommendation intention.

\section{J. Mediated Effect of Perceived Value}

The perceived value of consumers is recognized as one of the very important factors in making indepth decisions on consumer behavior such as purchase intention, recommendation intention, and re-visitation intention. [52] investigated the mediating role of perceived value in the effects of TV advertisement attributes of eco-friendly food on consumers' perceived value, product trust, and purchase intention. [53] confirmed the influential relationship between the VMD components of duty-free shops and shopping satisfaction by using hedonic value and practical value as parameters in their VMD (Visual Merchandising) component study of duty-free shops. [54] proved the partial mediating role of the characteristics of mobile social commerce and the hedonistic value of purchase intention. Based on this relationship, the following hypothesis was established.

Hypothesis 9: Perceived value will mediate the relationship between influencers' charm and recommendation intention.

Hypothesis 10: Perceived value will mediate the relationship between influencers' expertise and recommendation intention. 


\section{RESEARCH MODEL AND ANALYSIS}

This study intends to examine the effect of influencer influence on recommendation intention through an empirical analysis of the mediating effect of immersion and perceived value in TikTok live commerce in China. Therefore, the model of this study is as follows(Fig.1).

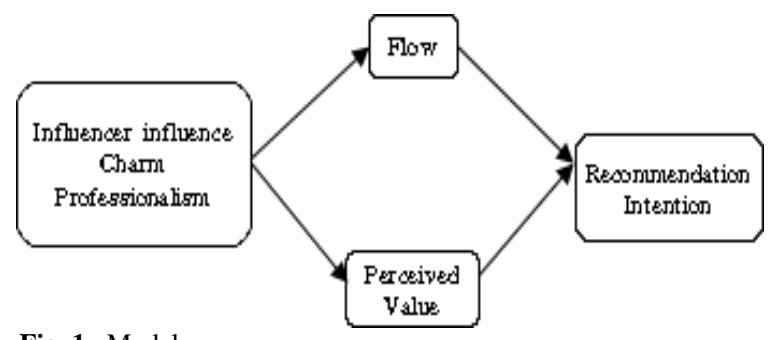

Fig. 1. Model

\section{A. Research Subject and Data Collection}

The study conducted a survey with Chinese students in mainland China and Chinese students in Korea who had purchase experience on TikTok live commerce in China through 'wenjuanxing', a Chinese research company. The survey was conducted for 9 days from July 28 to August 5, 2021, and a total of 350 copies were distributed. Of the 331 questionnaires collected, 313 copies were used for empirical analysis, excluding 18 copies due to poor responses.

\section{B. Operational Definition and Measurement of Variables}

In this study, the effect of influencers was set as 2 sub-variables, charm and professionalism, Based on previous studies, charm refers to the degree to which consumers perceive an influencer positively, and it can be observed that it includes psychological charm such as physical charm, ability, personality, and personality [10-11, 55] and [55] modified and supplemented three items used in the study, and measured it on a Likert 5point scale. Expertise holds the meaning that an influencer has specific knowledge, skills, experience, or ability in a specific field or product [56-58], adjusted and supplemented 3 items from a study to measure as a Likert 5-point scale.
In addition, immersion is a mental state where an individual that is not interested in anything else when using live commerce, is unaware of the passage of time, and continues to be immersed in live broadcasting [17-18, 59]. It corrected and supplemented the 3 items used in [59] and measured on a 5-point Likert scale. Perceived value is the overall ability to satisfy customers' needs with a provided product or service, which is what consumers evaluate, and is divided into practical value and hedonistic value [19-20, 6061] where three items were modified and supplemented and measured on a Likert 5-point scale in [50]. Recommendation intention is said to be an exchange process of communication that positively recommends to others through consumers' personal experiences [62, 29, 63], where 4 passages were modified and supplemented, and measured on a Likert 5-point scale in [63].

\section{AnAlysis Results}

\section{A. Demographic Analysis}

As a result of analyzing the demographic characteristics of the survey subjects, there were 174 women (55.59\%) and 139 men (44.41\%). Based on age, there were 17 people in their teens $(5.43 \%), 141$ people in their 20s $(45.05 \%), 91$ people in their 30s $(29.07 \%), 43$ people in their 40s (13.74\%), and 21 people in their 50s or older $(6.71 \%)$. Based on occupation, there were 68 students (21.73\%), 65 office workers (20.77\%), 64 civil servants (20.45\%), 33 self-employed $(10.54 \%)$, and 83 others (26.52\%). According to average monthly income, there are 72 individuals with RMB 2000-3000 (23\%), 82 with RMB 30005000 (26.2\%), 76 with RMB 5000-8000 (24.28\%), 36 with RMB 8000-10000 (11.5\%), and 47 with more than RMB 10000 (15.02\%). For the average viewing time of TikTok live streaming per day, 204 people watched less than 1 hour $(65.18 \%), 61$ people watched 1-2 hours (19.49\%), 30 people watched 2-3 hours $(9.58 \%), 10$ people watched 34 hours $(3.19 \%)$, and 8 people $(2.56 \%)$ watched for more than 4 hours. 19 people $(6.07 \%)$ replied that they do not know about TikTok influencers at 
all, 64 people (20.45\%) claimed to not know, 163 people $(52.08 \%)$ were average, 57 people $(18.21 \%)$ claimed to know about Tik Tok, while 10 people (3.19\%) claimed that they knew.

\section{B. Factor, Reliability, and Correlation Analysis}

In this study, the reliability of the variables was tested using spss24.0, and the credibility of each item was secured, as the Cronbach's value of all variables was 0.7 or higher. The KMO value was 0.948 , demonstrating that the data collected by the survey is valid for factor analysis. The analysis results are shown in $\langle$ Table 1$\rangle$.

Table 1. RELIABILITY AND VALIDITY ANALYSIS RESUlTS

\begin{tabular}{|c|c|c|c|c|c|c|c|}
\hline \multirow{2}{*}{ Variable } & \multirow{2}{*}{$\begin{array}{l}\text { Ques } \\
\text { tion }\end{array}$} & \multicolumn{5}{|c|}{ Component } & \multirow{2}{*}{$\begin{array}{l}\text { Cronb } \\
\text { ach' } \alpha\end{array}$} \\
\hline & & 1 & 2 & 3 & 4 & 5 & \\
\hline \multirow{3}{*}{ Flow } & 1 & 0.837 & 0.126 & 0.242 & 0.010 & 0.142 & \multirow{3}{*}{.858} \\
\hline & 2 & 0.815 & 0.087 & 0.204 & 0.207 & 0.235 & \\
\hline & 3 & 0.777 & 0.230 & 0.163 & 0.220 & 0.185 & \\
\hline \multirow{3}{*}{ Expertise } & 1 & 0.117 & 0.832 & 0.110 & 0.342 & 0.162 & \multirow{3}{*}{.883} \\
\hline & 2 & 0.227 & 0.814 & 0.244 & 0.249 & 0.164 & \\
\hline & 3 & 0.177 & 0.696 & 0.327 & 0.195 & 0.319 & \\
\hline \multirow{3}{*}{$\begin{array}{l}\text { Perceived } \\
\text { Value }\end{array}$} & 1 & 0.364 & 0.247 & 0.652 & 0.242 & 0.296 & \multirow{3}{*}{.900} \\
\hline & 2 & 0.247 & 0.222 & 0.762 & 0.306 & 0.276 & \\
\hline & 3 & 0.283 & 0.239 & 0.774 & 0.290 & 0.225 & \\
\hline \multirow{3}{*}{ Charm } & 1 & 0.237 & 0.309 & 0.370 & 0.676 & 0.141 & \multirow{3}{*}{.881} \\
\hline & 2 & 0.185 & 0.237 & 0.235 & 0.798 & 0.292 & \\
\hline & 3 & 0.086 & 0.377 & 0.218 & 0.743 & 0.261 & \\
\hline \multirow{4}{*}{$\begin{array}{c}\text { Recomme } \\
\text { ndation } \\
\text { Intention }\end{array}$} & 1 & 0.420 & 0.330 & 0.365 & 0.161 & 0.594 & \multirow{4}{*}{.919} \\
\hline & 2 & 0.335 & 0.217 & 0.220 & 0.373 & 0.745 & \\
\hline & 3 & 0.201 & 0.257 & 0.357 & 0.445 & 0.624 & \\
\hline & 4 & 0.296 & 0.331 & 0.454 & 0.238 & 0.588 & \\
\hline \multirow{2}{*}{\multicolumn{2}{|c|}{$\begin{array}{c}\text { Characteristic } \\
\text { Value }\end{array}$}} & 9.5 & 1.4 & 0.8 & 0.6 & 0.5 & \\
\hline & & 93 & 74 & 53 & 63 & 44 & \\
\hline \multirow{2}{*}{\multicolumn{2}{|c|}{$\begin{array}{c}\text { Explanation Rate } \\
(\%)\end{array}$}} & 59. & 9.2 & 5.3 & 4.1 & 3.4 & \\
\hline & & 957 & 14 & 34 & 45 & 02 & \\
\hline \multirow{2}{*}{\multicolumn{2}{|c|}{$\begin{array}{c}\text { Accumulation Rate } \\
(\%)\end{array}$}} & 59. & 69. & 74. & 78. & 82. & \\
\hline & & 957 & 171 & 505 & 650 & 052 & \\
\hline \multicolumn{8}{|c|}{$\mathrm{KMO}=0.948(\mathrm{sig}=.000)$} \\
\hline
\end{tabular}

According to the correlation analysis of variables, both charm and professionalism of influencers displayed a positive $(+)$ correlation with commitment and perceived value, as well as a positive (+) influence of commitment and perceived value on recommendation intention. The analysis results are shown in $\langle$ Table 2$\rangle$.
Table 2. CORRELATION ANALYSIS RESULT

\begin{tabular}{|c|c|c|c|c|c|}
\hline & Charm & $\begin{array}{l}\text { Professi } \\
\text { onalism }\end{array}$ & Flow & $\begin{array}{c}\text { Perceive } \\
\text { d Value }\end{array}$ & $\begin{array}{c}\text { Recommen } \\
\text { dation } \\
\text { Intention }\end{array}$ \\
\hline Charm & 1 & & & & \\
\hline $\begin{array}{l}\text { Professionali } \\
\text { sm }\end{array}$ & $.708^{* * *}$ & 1 & & & \\
\hline Fow & $.484^{* * *}$ & $.479^{* * *}$ & 1 & & \\
\hline $\begin{array}{l}\text { Perceived } \\
\text { Value }\end{array}$ & $.712^{* * *}$ & $.647^{* * *}$ & $.639^{* * *}$ & 1 & \\
\hline $\begin{array}{l}\text { Recommend } \\
\text { ation } \\
\text { Intention }\end{array}$ & $.756^{* * *}$ & $.703^{* * *}$ & $.667^{* * *}$ & $.811^{* * *}$ & 1 \\
\hline \multicolumn{6}{|c|}{${ }^{* * *} p<.001 .^{* *} p<.01 .{ }^{*} p<.05$} \\
\hline
\end{tabular}

\section{Hypothesis Testing}

In this study, multiple regression analysis was performed to test the hypothesis. According to the analysis results in <Table 3>, influencer influence had a positive effect on immersion (attraction, $\beta=0.484, \quad \mathrm{t}=9.765, \quad \mathrm{P}<0.05$ ), (professionalism, $\beta=0.479, \mathrm{t}=9.627, \mathrm{P}<0.05)$ Therefore, Hypothesis 1 and Hypothesis 2 are substantiated.

Table 3. Regression ANALYSIS RESUlts OF Hypothesis 1-2

\begin{tabular}{|c|c|c|c|c|c|c|}
\hline \multicolumn{2}{|c|}{ Model } & \multicolumn{2}{|c|}{$\begin{array}{l}\text { Unstandardized } \\
\text { Coefficients }\end{array}$} & \multirow{2}{*}{$\begin{array}{c}\begin{array}{c}\text { Standardized } \\
\text { Coefficients }\end{array} \\
\beta\end{array}$} & \multirow{2}{*}{$\mathrm{t}$} & \multirow{2}{*}{$p$} \\
\hline $\begin{array}{l}\text { Independent } \\
\text { Variable }\end{array}$ & $\begin{array}{l}\text { Dependency } \\
\text { Variable }\end{array}$ & B & $\begin{array}{l}\text { Standard } \\
\text { Error }\end{array}$ & & & \\
\hline Charm & Flow & .524 & .054 & .484 & 9.765 & .000 \\
\hline \multicolumn{7}{|c|}{$R^{2}=.235$ (Ajusted $R^{2}=.232$ ) $F=95.345 P=.000$ Durbin-Watson $=1.752$} \\
\hline Expertise & Flow & .509 & .053 & .479 & 9.627 & .000 \\
\hline \multicolumn{7}{|c|}{$R^{2}=.230\left(\right.$ Ajusted $R^{2}=.227 F=245.747 P=.000$ Durbin-Watson=1.686 } \\
\hline
\end{tabular}

The results of the analysis <Table 4> revealed that influencer influence had a positive effect on perceived value (attraction, $\beta=0.712, \mathrm{t}=17.891$, $\mathrm{P}<0.05$ ), (professionalism, $\beta=0.647, \mathrm{t}=14.947$, $\mathrm{P}<0.05)$. Therefore, Hypothesis 3 and Hypothesis 4 are substantiated.

Table 4. Regression AnAlysis RESUlts OF HypOthesis 3-4

\begin{tabular}{|c|c|c|c|c|c|c|}
\hline \multicolumn{2}{|c|}{ Model } & \multicolumn{2}{|c|}{$\begin{array}{c}\text { Unstandardized } \\
\text { Coefficients }\end{array}$} & $\begin{array}{c}\text { Standardized } \\
\text { Coefficients }\end{array}$ & \multirow{2}{*}{$\mathrm{t}$} & $p$ \\
\cline { 1 - 4 } $\begin{array}{c}\text { Independent } \\
\text { Variable }\end{array}$ & $\begin{array}{c}\text { Dependent } \\
\text { Variable }\end{array}$ & B & $\begin{array}{c}\text { Standard } \\
\text { Error }\end{array}$ & $\beta$ & & \\
\hline Charm & $\begin{array}{c}\text { Perceived } \\
\text { Value }\end{array}$ & .719 & .040 & .712 & 17.891 & .000 \\
\hline
\end{tabular}

$R^{2}=.507$ (Ajusted $\left.R^{2}=.506\right) F=320.095 P=.000$ Durbin-Watson=1.937 


\begin{tabular}{|c|c|c|c|c|c|c|}
\hline Expertise & $\begin{array}{c}\text { Perceived } \\
\text { Value }\end{array}$ & .641 & .043 & .647 & 14.947 & .000 \\
\hline$R^{2}=.418$ (Ajusted $R^{2}=.416 F=223.400 P=.000$ Durbin-Watson=1.909 \\
\\
***:p<.001, **:p<.01, *:p<.05 (Dependent Variable: SS)
\end{tabular}

According to the analysis results in $\langle$ Table 5>, it was found that commitment had a positive effect on recommendation intention $(\beta=0.666, \mathrm{t}=15.788$, $P<0.05)$. Therefore, hypothesis 5 was substantiated.

Table 5. REgRESSION ANALYSIS RESULTS OF HyPOTHESIS 5

\begin{tabular}{|c|c|c|c|c|c|c|}
\hline \multicolumn{2}{|c|}{ Model } & \multicolumn{2}{|c|}{$\begin{array}{c}\text { Unstandardized } \\
\text { Coefficients }\end{array}$} & $\begin{array}{c}\text { Standardize } \\
\mathrm{d} \\
\text { Coefficients }\end{array}$ & $\mathrm{t}$ & $p$ \\
\cline { 1 - 4 } $\begin{array}{c}\text { Independen } \\
\mathrm{t} \text { Variable }\end{array}$ & $\begin{array}{c}\text { Dependent } \\
\text { Variable }\end{array}$ & $\mathrm{B}$ & $\begin{array}{c}\text { Standar } \\
\mathrm{d} \text { Error }\end{array}$ & $\beta$ & & \\
\cline { 1 - 5 } Flow & $\begin{array}{c}\text { Recommendatio } \\
\mathrm{n} \text { Intention }\end{array}$ & $\begin{array}{c}.66 \\
6\end{array}$ & .042 & .667 & $\begin{array}{c}15.78 \\
8\end{array}$ & $\begin{array}{c}.00 \\
0\end{array}$ \\
\hline \multicolumn{7}{|c|}{$R^{2}=.445$ (Ajusted $R^{2}=.443$ ) $F=249.252 P=.000$ Durbin-Watson=1.698 } \\
\hline
\end{tabular}

The analysis results in <Table 6> revealed that perceived value had a positive effect on recommendation intention $(\beta=0.666, t=15.788$, $\mathrm{P}<0.05)$. Therefore, hypothesis 6 is substantiated.

Table 6. REgRESSION ANALYSIS RESULTS OF HYPOTHESIS 6

\begin{tabular}{|c|c|c|c|c|c|c|}
\hline \multicolumn{2}{|c|}{ Model } & \multicolumn{2}{|c|}{$\begin{array}{l}\text { Unstandardized } \\
\text { Coefficients }\end{array}$} & \multirow{2}{*}{$\begin{array}{c}\begin{array}{c}\text { Standardize } \\
\mathrm{d} \\
\text { Coefficients }\end{array} \\
\beta\end{array}$} & \multirow{2}{*}{$\mathrm{t}$} & \multirow{2}{*}{$p$} \\
\hline $\begin{array}{c}\text { Independen } \\
\mathrm{t} \text { Variable }\end{array}$ & $\begin{array}{c}\text { Dependent } \\
\text { Variable }\end{array}$ & B & $\begin{array}{l}\text { Standar } \\
d \text { Error }\end{array}$ & & & \\
\hline $\begin{array}{l}\text { Perceived } \\
\text { Value }\end{array}$ & $\begin{array}{l}\text { Recommendatio } \\
\text { n Intention }\end{array}$ & $\begin{array}{c}.86 \\
8\end{array}$ & .036 & .811 & $\begin{array}{c}24.42 \\
4\end{array}$ & $\begin{array}{c}.00 \\
0\end{array}$ \\
\hline \multicolumn{7}{|c|}{$R^{2}=.657\left(\right.$ Ajusted $\left.R^{2}=.656\right) F=596.518 P=.000$ Durbin-Watson $=1.941$} \\
\hline
\end{tabular}

Mediated regression analysis was performed to verify the mediating effect of commitment and perceived value in the effect of influencer influence (attraction, professionalism) on recommendation intention. According to the analysis results in $\langle$ Table 7$\rangle$, the standardized regression coefficient values of charm and professionalism, the independent variables of step 3 were less than the values of step 2, so it was verified that there was a partial mediating effect of the parameter. Therefore, Hypothesis 7 and Hypothesis 8 are substantiated.
Table 7. MEdiating EFFECT OF FLOW

\begin{tabular}{|c|c|c|c|c|c|c|}
\hline & \multicolumn{3}{|c|}{ Stage 2} & \multicolumn{3}{|c|}{ Stage 3} \\
\hline & $\beta$ & $t$ & VIF & $\beta$ & $t$ & VIF \\
\hline Charm & .756 & 20.357 & 1.000 & .565 & 15.631 & 1.307 \\
\hline Flow & & & & 393 & 10.868 & 1.307 \\
\hline$R^{2}$ & \multicolumn{3}{|c|}{$.571(.570)$} & \multicolumn{3}{|c|}{$.690(.688)$} \\
\hline $\begin{array}{c}\text { Adjusted } \\
R^{2}\end{array}$ & \multicolumn{3}{|c|}{ - } & \multicolumn{3}{|c|}{$.119(.118)$} \\
\hline$F$ & \multicolumn{3}{|c|}{$414.416^{6 * * *}$} & \multicolumn{3}{|c|}{$344.297^{* * *}$} \\
\hline Expertise & .703 & 17.413 & 1.000 & .497 & 12.723 & 1.298 \\
\hline Flow & & & & .429 & 10.973 & 1.298 \\
\hline$R^{2}$ & \multicolumn{3}{|c|}{$.494(.492)$} & \multicolumn{3}{|c|}{$.635(.633)$} \\
\hline $\begin{array}{c}\text { Adjusted } \\
R^{2}\end{array}$ & \multicolumn{3}{|c|}{ - } & \multicolumn{3}{|c|}{$.141(.141)$} \\
\hline$F$ & \multicolumn{3}{|c|}{$303.212^{* * * *}$} & \multicolumn{3}{|c|}{$270.020^{* * * *}$} \\
\hline
\end{tabular}

The results of the analysis in <Table 8> displayed that the standardized regression coefficient values of charm and professionalism, the independent variables of step 3, were less than the values of step 2, so it was verified that there was a partial mediating effect of the perceived value as a parameter. Therefore, Hypothesis 8 and Hypothesis 9 are substantiated.

Table 8. Mediating Effect of Perceived Value

\begin{tabular}{|c|c|c|c|c|c|c|}
\hline & \multicolumn{3}{|c|}{ Stage 2} & \multicolumn{3}{|c|}{ Stage 3} \\
\hline & $\beta$ & $t$ & VIF & $\beta$ & $t$ & $V I F$ \\
\hline Charm & .756 & 20.357 & 1.000 & .362 & 8.487 & 2.029 \\
\hline $\begin{array}{l}\text { Perceived } \\
\text { Value }\end{array}$ & & & & .553 & 12.958 & 2.029 \\
\hline$R^{2}$ & \multicolumn{3}{|c|}{$.571(.570)$} & \multicolumn{3}{|c|}{$.722(.720)$} \\
\hline Adjusted $R^{2}$ & \multicolumn{3}{|c|}{-} & \multicolumn{3}{|c|}{$.151(.150)$} \\
\hline$F$ & \multicolumn{3}{|c|}{$414.416^{* * *}$} & \multicolumn{3}{|c|}{$402.382^{* * *}$} \\
\hline Expertise & .703 & 17.413 & 1.000 & .307 & 7.673 & 1.718 \\
\hline $\begin{array}{l}\text { Perceived } \\
\text { Value }\end{array}$ & & & & .613 & 15.331 & 1.718 \\
\hline$R^{2}$ & \multicolumn{3}{|c|}{$.494(.492)$} & \multicolumn{3}{|c|}{$.712(.710)$} \\
\hline Adjusted $R^{2}$ & \multicolumn{3}{|c|}{ - } & \multicolumn{3}{|c|}{$.218(.218)$} \\
\hline$F$ & \multicolumn{3}{|c|}{$303.212^{* * *}$} & \multicolumn{3}{|c|}{$383.203^{* * *}$} \\
\hline
\end{tabular}

\section{Conclusion}

\section{A. Results and Implications}

This study verified the influence of influencers' charm and professionalism on recommendation intention while focusing on TikTok live commerce 
in China, through empirical analysis on the mediating effect of immersion and perceived value. As a result of empirical analysis, it was found that the charm and professionalism of influencers had a significant effect on recommendation intention, and the mediating effect of commitment and perceived value was also verified.

Based on these results, it was confirmed that the charm and professionalism of influencers in China's TikTok live commerce are important factors that can increase users' recommendation intention, and it can be considered to be used preferentially for future studies in the live commerce field.

On the other hand, according to the survey results, more than half of the respondents selected 'Average', 'Not at all', or 'Not at all' for all the questions regarding the charm and professionalism of influencers. Therefore, it is implied that active influencers or companies that are utilizing influencers should focus on this aspect and supplement and improve on this idea, and develop and provide better content and services to reach the level of consumer immersion and perceived value so that consumers are not only induced to make purchases but also further induced to make recommendations. When an influencer conducts a broadcast, not only physical charm such as appearance and style, but also psychological charm such as humor and an unique personality may appeal to the good will of consumers, as well as professional understanding and explanation of related fields that positively affect consumers' personal intellectual level and values. Like this, by making the consumer feel the hedonistic or practical value as well as extreme immersion, the recommendation intention can be enhanced.

\section{B. Limitations and Directions of Future Study}

Although this study broadened its scope of research in the field of live commerce and influencer influence and supplemented existing studies, it has the following limitations.

First, the study only analyzed the TikTok application in China, so it is uncertain whether it can be applied to other applications that have live commerce functions. Hence, it may lack universality. In addition, the research scope of this study is limited to China, so it is necessary to examine or conduct comparative studies on live commerce platforms in various cultures beyond China.

Second, this study simply examined the characteristics of general influencers without subdividing the types of influencers. Since each characteristic factor, immersion experience, perceived value, recommendation intention, etc. may vary depending on the type of influencer, it is necessary to categorize the type of influencer and study them in detail in future research.

Third, in this study, the characteristics of influencers are limited to two dimensions: charm and professionalism. Therefore, a more meaningful study may be conducted if other characteristics of live streaming influencers are selected and measured in subsequent studies.

\section{REFERENCES}

[1] Son, D. J., \& Kim, H. K. (2017). A Study on the Government PR Using Social Media: Focused on the Differences in Perception between Government PR Practitioners and SNS Professionals, Journal of Practical Research in Advertising and Public Relations, 10(2), 64-95.

[2] ZOU, Y(2018). A Study of Chinese Internet Private Broadcasting Viewers' Viewing Satisfaction and Continue Viewing: Focusing on Viewing Motives, Influence of Parasocial Interaction and Identification, Master's thesis, Hanyang University .

[3] Hovland, C. I., \& Weiss, W. (1951). The influence of source credibility on communication effectiveness, Public opinion quarterly, 15(4), 635-650. DOI: $10.1086 / 266350$

[4] Zhang, M., \& Kim, M. H. (2020). Chinese Influence of the Characteristics; Personal Broadcasting; Purchasing Intention, Journal of The Korean Society of Illustration Research, 21(65), 127-138.

[5] Liu, M. Q., Park, J. Y., \& Lee, H. E. (2021). Technology Acceptance Model in Live Commerce Context: The Effect of Para-social Interactivity and SourceCharacteristics on Consumers' Shopping Intention on Live Commerce Platform, Journal of The Korea Contents Association, 21(6), 2021.6, 138-154 DOI: 10.5392/JKCA.2021.21.06.138

[6] Kyung, W. L., \& Kyung, W. O. (2021). Effects of Wanghong marketing in live commerce on chinese consumers' purchase intention toward fashion products: Focusing on the mediating effect of Wanghong's characteristics and consumers' coexperience, Journal of the Korea Fashion \& Costume Design Association, 23(1), 2021.2, 19-36 DOI: $10.30751 / \mathrm{kfcda} .2021 .23 .1 .19$ 
[7] Song, Y. T., \& Lee, J. H. (2021). Effects of Live Commerce Attributes and Influencer Attributes on Repurchase Intention of Beauty and Fashion Products, Journal of Distribution and Management Research, 24(1), 37-56 DOI: $10.17961 / \mathrm{jdmr} .24 .01 .202102 .37$

[8] Chen, F., \& Lee, J. S.(2021). The Impact of the Educational Influencer Characteristics of the Short Video App Tik Tok on the Intention to Purchase Online Knowledge Content, A Journal of Brand Design Association of Korea, 19(2), 77-94 DOI: $10.18852 /$ bdak.2021.19.2.77

[9] Kim, S. J., \& Chul, M. H. (2021). Effects of Live Commerce and Show Host Attributes on Purchase Intention: Including the Mediating Effects of Content Flow, Asia-Pacific Journal of Business Venturing and Entrepreneurship, 16(3), 177-191

[10] McCroskey, J. C., \& McCain, T. A. (1974). The Measurement of Interpersonal Attraction, Speech Monographs, 41(3), 261-266. DOI: $10.1080 / 03637757409375845$

[11] Morrow, P. C., McElroy, J. C., Stamper, B. G., \& Wilson, M. A. (1990). The effects of physical attractiveness and other demographic characteristics on promotion decisions, Journal of Management, 16(4), 723-736.

DOI: $10.1177 / 014920639001600405$

[12] Liu, L. (2020). The Effect of Influencer Characteristics on Flow and Psychological Responses in China, Journal of International Trade \& Commerc, 16(2), 405-421

DOI: $10.16980 /$ jitc.16.2.202004.405

[13] Lee, M. T., Lee, J. Y., \& Shim, S. O. (2020). An exploratory study on the effect of Youtube beauty influencer attributes on contents attitude, product attitude, word of mouth intention, and purchase intention, Korea Advertising Society, 31(5), 117-142.

[14] Kim, Y. S. (2005). Persuasive communication. Nanam Print.

[15] Liu, X. Y., Park, J. Y., \& Lee, H. E. (2020). The Effect of Wang-Hong Characteristics on Impulse Buying During Live Sale: Based on Women's Clothing Sales in China, Journal of The Korea Contents Association, 20(4), 212-229 DOI: 10.5392/JKCA.2020.20.04.212

[16] Kwak, J. H., \& Yoh, E. N. (2021). Effect of Influencers' Characteristics and Consumer Need Satisfaction on Attachment to Influencer, Content Flow and Purchase Intention, Journal of the Korean Society of Clothing and Textiles, 45(1), 56-72 DOI: $10.58550 / J K S C T .2021 .45 .1 .56$

[17] Csikszentmihalyi, M. (1974). Flow: Studies of enjoyment, University of Chicago.

[18] Lutz, R. L., \& Guiry, M. (1994). Intense Consumption Experience: Peaks,Performances, and Flow, Winter Marketing Educators Conference.

[19] Zeithaml, V. A. (1988). Consumer perceptions of price, quality, and value: a means-end model and synthesis of evidence. Journal of marketing, 52(3), 222

DOI: $10.1177 / 002224298805200302$
[20] Sheth, J. N., Newman, B. L. \& Gross, B. L. (1991). Why We Buy What We Buy : A Theory of Consumption Values, Journal of Business Research, 22(2), 159-170 DOI: $10.1016 / 0148-2963(91) 90050-8$

[21] Lee, W. J., \& Jeon, A. E. (2016). The Role of Top Management Team: Aviation Service Industry Competitiveness, Joumal of Aviation Managment Society of Korea, 14(2), 47-73

[22] Yu, J. W. (2020). The Effects of Perceived Value, Brand Equity, Satisfaction and Recommendation Intention in the Coffee Specialty Shop, Event \& Convention Research, 16(3), 143-161 DOI: $10.31927 /$ asec. 16.3 .8

[23] Lee, J. h. (2021). A Study on the Five Star Hotel Eeffects of Satisfaction from the Perceived Value of Customers Spending their Staycation at 5-Star Hotels in Korea on Trust and the Intention to give a Recommendation, Journal of Tourism Management Research, 25(3), 381-401 DOI: $10.18604 /$ tmro.2021.25.3.19

[24] Hansen, H., Samuelsen, B. M., \& Silseth, P. R. (2008). Customer Perceived Value in B-t-B Service Relationships: Investigating the Importance of Corporate Reputation, Industrial Marketing Management, 37, 206-217.

DOI: 10.1016/j.indmarman.2006.09.001

[25] Kettinger, W. J., Park, S. H. \& Smith, J. (2009). Understanding the Consequences of Information Systems Service Quality on IS Service Reuse, Information and Management, 46(6), 335-341. DOI: 10.1016/j.im.2009.03.004

[26] Parasuraman, A., \& Grewal, D. (2000). The im-pact of technology on the quality-val-ue-loyalty chain : A research agenda, Journal of the Academy of Marketing Science, 28(1), 168-174. DOI: $10.1177 / 0092070300281015$

[27] Mcdougall, G., \& Levesque, T. (2000). Customer satisfaction with services : Putting per-ceived value into the equation, Journal of Service marketing, 14(5), 392-410. DOI: $10.1108 / 08876040010340937$

[28] Cronin, J. J., \& Taylor. S. A. (1992). Measuring service quality : Areexamination \& extensin, Journal of Marketing, 56, 55-68. DOI: $10.1177 / 002224299205600304$

[29] Seo, H. O. (2016), A Study on The Impact of Perceived Value by Customer's Involvement in Casino on Satisfaction and Revisit Intention, Ph.D. dissertation, Kyung Hee University

[30] Richins, L. M. (1997). Measuring emotions as the consumption experience, Journal of Consumer Research, 24, 127-146. DOI: $10.1086 / 209499$

[31] Oh, Y. M. (2015). A Study on Customer Satisfaction, Revisit Intention and Intention of Recommendation According to Hotel Selection Attributes of Businesswomen, Master's thesis, Kyung Hee University

[32] Schindler, R. M., \& Bickart, B. (2005). Published word of mouth: Referable, consumer-generated information on the Internet, Online consumer psychology: Understanding and influencing consumer behavior in the virtual world, 32, 35-61. 
[33] Lee, C. h. (2021). A Study on the Effect of Mobile Live Commerce Characteristics on the Intention to Purchase, Ph.D. dissertation, Soongsil University

[34] Li, J. L. (2021). The Influence of Creator Characteristics of Short Knowledge Video on Purchase Intention and Recommendation Intention: The Moderating Effect of Usage Motivation, Master's thesis, Hanyang University

[35] Kim, H., \& An, B. (2018). A Study on the Effects of the attractiveness and credibility of Online 1 Personal Media Broadcasting BJ on the Viewing Engagement perceived on Media Channel, Interactivity, Perceived Enjoyment, and the User's Responses. Article in Korean. Advert Res, 118, 78-126.

DOI: $10.16914 / \mathrm{ar}$

[36] Oh, J. C., \& Hwang, S. H. (2018). A Study on Viewing Satisfaction and Subscriptive Intention of Personal Creator Broadcasting Viewer : Moderating Effect ofSelf-Congruity and Customer Innovativeness, The e-Business Studies, 19(6), 137-157 DOI: $10.20462 /$ tebs.2018.12.19.6.137

[37] Bansal, H. S., \& Voyer, P. A. (2000). Word-of-mouth processes within a services purchase decision context, Journal of service research, 3(2), 166-177. DOI: $10.1177 / 109467050032005$

[38] Kim, S., Kim S. Y., Son S, Z., \& Lee, T. W. (2017). You look like an ad, you look like an ad, not an ad, influencer marketing, Excellence Marketing for Customer, 51(5), 56-66

[39] Song, S. Y. (2021). The effect of SNS influencers' characteristics on consumer behavior: Verification of the mediated value of perceived value and the adjustment effect of educational background, Ph.D. dissertation, Hyupsung University

[40] Roh, J. H. (2021). A Study on Semiotic Analysis of Modern Consumption regarding the Purchase Intention of Live Commerce, Ph.D. dissertation, Inha University

[41] Bettencourt, L. A. (1997). Customer Voluntary Performance: Customers As Partners in Service Delivery, Journal of Retailing, 73(3), 383-406. DOI: $10.1016 / \mathrm{S} 0022-4359(97) 90024-5$

[42] Jun, C. S., Kim, H. S., \& Shin, S. H. (2011). The Effect of European Professional Football TV Viewers Motives on Viewing Flow, Re-viewing Intention, and Word-of-mouth, Korean Society For Sport Management, 16(3), 73-85

[43] Kim, S. S., Han, J. S., \& Joung, Y. S. (2013). Influence of the Brand Community Characteristic of a Restaurant Business on Commitment andRecommendation Intentions, International Journal of Tourism and Hospitality Research, 27(1), 203-219

[44] Kwak, B. S. (2013). The Influence of SNS Properties on Involvement, Reliability, and Behavior Intention in Restaurants, Northeast Asia tourism research, 9(2), 103-123

[45] Park, S. G. (2019). Influence of Fairness of Franchise Headquarters on Renewal Intention and Recommendation Intention: Focusing on the Quality Effect of Relationship, Ph.D. dissertation, Honam University

[46] Jeon, J. A., \& Ahn, D. H. (2017). A Study on the Deluxe Hotel Customers in Relationship with
Perceived Value, Customer Satisfaction and Intention ofRevisiting and Recommendation, Journal of Tourism and Leisure Research, 19(3), 49-68

[47] Lai, F., Griffin, M., \& Babin, B. J. (2009). How Quality, Value, Image, and Satisfaction Create Loyalty at a Chinese Telecom. Journal of Business Research, 62, 980-986.

DOI: $10.1016 /$ j.jbusres.2008.10.015

[48] Kim T. K., \& Bae, M. G. (2013). Effect of Brand Image on Customer's Value, Satisfaction and Intentions of Recommendation in Hotel Industry, Northeast Asia tourism research, 9(2), 39-58

[49] Yi, K. S., \& Jun, B. R. (2018). The effect of tourism choice attributes on perceived values and behavior intension: Chinese tourist visiting Korea, Journal of Tourism Management Research, 22(7), 583-601 DOI: $10.18604 / \mathrm{tmro} .2018 .22 .7 .28$

[50] Ju, S. H., Song, M. Y., \& Kim, B. K. (2018). The Effect of Personal trait on Perceived Value and Recommendation Intention : Focus on one-person media contents, Journal of the Korea Convergence Society, 22(7), 583-601

DOI : $10.18604 /$ tmro.2018.22.7.28

[51] Ok, S. B. (2016). A Study on Afreeca TV Use and the Mediating Role of Flow Experience, Kroean Journal of Communication Studies, 24(1), 83-109

[52] Kim, H. J. (2016). The Effect of Environmentalfriendly food Commercial Advertising Attributes on Perceived Value, Trust and Purchase Intention, International Journal of Tourism and Hospitality Research, 30(1), 51-64

[53] Yoo, Y. Y., Kim, I. S., Hwang, S. J., \& Hyun, S. H. (2017). The Effects of Duty-free Shops' VMD Factors on Hedonic Value, Utilitarian Value, and Shopping Satisfaction, International Journal of Tourism Management and Sciences, 32(1), 19-36 DOI: $10.21719 /$ KJTR.32.1.2

[54] Choi, B. N. (2017). The Effects of Mobile Social Commerce Characteristics on the Purchase Intention: Focusing on the Mediating Effects of Shopping Values, $\mathrm{Ph}$.D. dissertation, Anyang University

[55] Kim, S. S., Seo, J. M., \& Kim, M. J. (2009). A Study of Hayllu Celebrity Marketing through Investigating the Effects of Hallyu Celebrities' Advertising Attributes onCreating Company`s Image, Reliance, and Customer Loyalty: Focused on Japanese Tourists Who Visit Lotte Hotel \& Resort, Korean Journal of Hospitality \& Tourism, 18(4), 217-243

[56] Birnbaum. \& stegne. (1979). Source Credibility in Social Judgement: Bias, Expertis, and the Judge's Point of View, Jaurmal of Personality and Social Psychology, 37, 48-74.

DOI: $10.1037 / 0022-3514.37 .1 .48$

[57] Szymanski, D. M., \& Hise, R. T. (2000). Esatisfaction: an initial examination, Journal of retailing, 76(3), 309-322.

DOI: $10.1016 / \mathrm{S} 0022-4359(00) 00035-\mathrm{X}$

[58] Shimp, T. A. (2010). Integrated Marketing Communication in Advertising and Promotion/por Terence A Shimp, No. 658. 8 S45.

[59] Song, Y. T. (2021). The Effects of Live Commerce Customer's Repurchase Intention: Focused on Beauty, Fashion and Entertainment, Ph.D. dissertation, Kongju National University 
[60] Sweeney, J. C., \& Soutar, G. N. (2001). Consumer perceived value: The development of a multiple item scale, Journal of retailing, 77(2), 203-220.

DOI: 10.1016/S0022-4359(01)00041-0

[61] Turel, O., Serenko, A., \& Bontis, N. (2007). User acceptance of wireless short messaging services: Deconstructing perceived value, Information \& Management, 44(1), 63-73.

DOI: $10.1016 /$ j.im.2006.10.005

[62] Gwinner, K. P., Gremler, D. D., \& Bitner, M. J. (1998). Relational benefits in services industries: the customer's perspective. Journal of the academy of marketing science, 26(2), 101-114.

DOI: $10.1177 / 0092070398262002$

[63] Jang, Y. H. (2019). A Study on Effects of Information Characteristics of E-WOM on Attendee's Attitudes and Behavior Intention in Exhibition and Convention, Event \& Convention Research, 36(0), 23-45

DOI: $10.31927 /$ asec. 15.4 .2 